\title{
SUSU SEGAR KAMBING ETAWA YANG DIFERMENTASI DALAM BAMBU BETUNG (Dendrocalamus Asper) DAN BAMBU TALI (Gigantochloa Apus) SEBAGAI PROBIOTIK BAKTERI ASAM LAKTAT
}

\section{ETAWA GOOD FRESH MILK FERMENTED IN BAMBOO (Dendrocalamus asper) AND (Gigantochloa apus) AS A PROBIOTIC OF LACTIC ACID BACTERIA}

\author{
Ni Nyoman Tria Febrina ${ }^{1}$, Syamsul Bahri ${ }^{2}$, Dewa Ayu Citra Rasmi ${ }^{2}$ \\ ${ }^{1}$ Mahasiswa Program Studi Pendidikan Biologi, Jurusan Pendidikan MIPA, FKIP Universitas Mataram \\ ${ }^{2}$ Program Studi Pendidikan Biologi, Jurusan Pendidikan MIPA, FKIP Universitas Mataram \\ *Email :syamsulsalihu@yahoo.com
}

Diterima: 11 Desember 2018. Disetujui: 06 Februari 2019. Dipublikasikan: 31 Maret 2019

\begin{abstract}
Abstrak: Telah dilakukan penelitian tentang potensi probiotik Bakteri Asam Laktat (BAL) dari susu segar kambing Etawa yang difermentasi dalam bambu Betung (Dendrocalamus asper) dan bambu Tali (Gigantochloa apus). Penelitian ini bertujuan untuk Mengetahui potensi probiotik BAL yang dihasilkan dari fermentasi susu segar kambing Etawa dalam bambu Betung (Dendrocalamus asper) dan bambu Tali (Gigantochloa apus). Jenis penelitian ini adalah deskriptif eksploratif. Uji probiotik mengacu pada ketahanan isolat terhadap $\mathrm{pH} 3,0$ dan uji ketahanan isolat terhadap garam empedu $0,3 \%$ dilakukan dengan metode tuang. Uji aktivitas antibakteri dilakukan dengan metode difusi agar. Ketahanan BAL yang diperoleh dari bambu Betung pada pH 3,0 sebesar 99,53\%, sedangkan ketahanan BAL dalam garam empedu $0,3 \%$ sebesar 94,74\%. Ketahanan BAL yang diperoleh dari bambu Tali tehadap $\mathrm{pH} 3,0$ sebesar 95.74\%, sedangkan ketahanan BAL dalam garam empedu 0,3\% sebesar 97.96\%. Aktivitas antibakteri Escherichia coli dari BAL yang diperoleh dari bambu Betung tergolong sedang yaitu menghasilkan zona bening sebesar 8-10 mm, sedangkan BAL yang diperoleh dari bambu Tali tidak menunjukkan adanya aktivitas penghambatan. Oleh karena itu BAL dari susu segar kambing Etawa yang difermentasi dalam bambu Betung berpotensi sebagai probiotik.
\end{abstract}

Kata Kunci: Bakteri Asam Laktat, Probiotik, Dadih, Susu Kambing Etawa.

Abstract: Research of potentiality of probiotic lactic acid bacteria (LAB) which are isolated from fresh milk Etawa goat fermented in Betung bamboo (Dendrocalamus asper) and Tali bamboo (Gigantochloa apus) have been conducted. The research aims to determine potentiality of probiotic LAB from fresh milk Etawa goat fermented in Betung bamboo (Dendrocalamus asper) and Tali bamboo (Gigantochloa apus). Type of this research is descriptive explorative. The probiotic test refers to Resistance of isolated bacteria in $\mathrm{pH} 3.0$ and $0.3 \%$ bile salt. Both test is performed by using the pour plate method. Antibacterial activity test are performed by using agar diffusion method. The resistance of LAB obtained from Betung bamboo in $\mathrm{pH} 3.0$ is $99.53 \%$, while the resistance of LAB in $0.3 \%$ bile salt is $94.74 \%$. The resistance of LAB obtained from Tali bamboo in pH 3.0 is $95.47 \%$, while the resistance of $\mathrm{LAB}$ in $0.3 \%$ bile salt is $97.96 \%$. Isolates obtained from Betung bamboo intermediately inhibited Escherichia coli growth (8-10 mm clear zone), whereas isolates obtained from Tali bamboo did not inhibited Escherichia coli growth. It is concluded that LAB isolated form fresh milk Etawa goat fermented in Betung bamboo is potentially candidate can be developed as a probiotic bacteria.

Keywords: Lactic Acid Bacteria, Probiotic, Dadih, Fresh Milk Etawa Goat

\section{PENDAHULUAN}

Susu adalah cairan bergizi berwarna putih yang dihasilkan oleh kelenjar susu mamalia. Secara kimiawi susu mempunyai susunan sebagai berikut: air $(87,20 \%)$, lemak $(3,70 \%)$, protein $(3,50 \%)$, laktosa $(4,90 \%)$, dan mineral $(0,07 \%)$ [1]. Menurut Darkuni (2001), susu Kambing Etawa mengandung laktosa sekitar 4,23\%. Susu ini tidak mengandung beta-lactoglobulin, yaitu senyawa alergen yang sering memicu reaksi seperti asma, infeksi radang telinga, kemerahan pada kulit, dan gangguan percernaan makanan [2].
Pengolahan susu dengan cara fermentasi menjadi produk seperti yoghurt, yakult, kefir, mentega, keju dan lain-lain sudah lama dilakukan oleh masyarakat. Di Indonesia khususnya Sumatra Barat, olahan susu fermentasi khas daerah tersebut adalah dadih. Dadih berasal dari susu kerbau dengan cara pengolahan yang sangat sederhana yaitu dengan memasukkan susu dalam ruas bambu selama \pm 24 jam sampai 2-3 hari sehingga terjadi fermentasi secara spontan. Dadih dikonsumsi sebagai lauk-pauk dan makanan selingan yang manfaatnya menyehatkan tubuh [3]. 
Mikroorganisme penyebab fermentasi dadih menginfeksi bambu pada tahap rebung dan hidup di dalam ruas-ruas bambu tersebut. Mikroorganisme tersebut terdiri atas bakteri dan khamir. Bambu yang digunakan untuk pembuatan dadih dipilih bambu yang sudah tua sehingga kadar air bambu relatif rendah, sehingga kualitas dadih lebih baik [4].

Produk susu fermentasi yoghurt, yakult dan minuman susu laktat lainnya tergolong produk pangan fungsional yang mengandung mikroba hidup yang bermanfaat terhadap kesehatan. Mikroba tersebut adalah bakteri asam laktat (BAL). Diketahui beberapa dari genus BAL merupakan bakteri probiotik. Makanan dan minuman probiotik memiliki manfaat kesehatan yaitu: membantu proses sistem pencernaan (enzim laktase, merangsang fungsi dinding usus) dan penyerapan zat gizi, menghambat dan membunuh bakteri patogen dalam saluran pencernaan seperti $E$. coli, $S$. aureus, $S$. typhimurium, v. cholerae, dan M. tubercolusis, mencegah konstipasi, sebagai anti kanker, menurunkan kolesterol darah, mencegah Lactose intolerant, meningkatkan respon imuno tubuh [4].

Bakteri probiotik merupakan bakteri yang dapat meningkatkan kesehatan manusia. Bakteri kandidat probiotik harus bertahan hidup dalam saluran pencernaan setelah dikonsumsi. Bakteri ini tahan terhadap lisozim, enzim di air liur, asam lambung, garam empedu dan memiliki aktivitas antibakteri. Serta mampu melekat pada sel epithelia, berkolonisasi dan menjaga keharmonisan komposisi bakteri saluran pencernaan [6].

Berdasarkan uraian tersebut di atas maka Potensi Probiotik Bakteri Asam Laktat dari Susu Segar Kambing Etawa yang Difermentasi dalam Bambu Betung (Dendrocalamus Asper) dan Bambu Tali (Gigantochloa apus)menarik untuk diteliti yang diharapkan dapat memberikan informasi dan bukti ilmiah untuk mengembangkan sumber probiotik dari makanan fermentasi khas Indonesia.

\section{METODE PENELITIAN}

Penelitian ini merupakan penelitian deskriptif eksploratif, yaitu menguji potensi probiotik dari bakteri asam laktat dari fermentasi susu segar kambing etawa dalam bambu Betung (Dendrocalamus asper) dan bambu Tali (Gigantochloa apus). Penelitian ini dilakukan pada bulan Oktober 2017 - Februari 2018 bertempat di Laboratorium Mikrobiologi Program Studi Pendidikan Biologi, Jurusan Pendidikan MIPA, Fakultas Keguruan dan Ilmu Pendidikan, Universitas Mataram.

\section{Fermentasi}

Bambu Betung dan bambu Tali diperoleh dari Kecamatan Narmada, masing-masing dengan panjang $25 \mathrm{~cm}$. Bambu diletakkan terbalik selama 1 malam sebelum memasukkan susu ke dalam bambu. Proses dimulai dengan pengisian susu segar
Kambing Etawa dari Kecamatan Labu Api yang baru diperas dengan volume $150 \mathrm{ml} /$ tabung bambu. Kemudian bambu ditutup dengan daun pisang dan inkubasi pada suhu ruang selama 48 jam dalam suhu ruangan [3] .

\section{Isolasi Bakteri Asam Laktat Dari Fermentasi Susu}

Isolasi bakteri dilakukan dengan mensuspensikan 1 gr dadih (fermentasi 48 jam), kedalam $9 \mathrm{ml}$ larutan $0,85 \% \mathrm{NaCl}$ (pengenceran $10^{-}$ $\left.{ }^{1}\right)$. Kemudian dibuat larutan garam fisiologis dengan pengenceran berseri sampai $10^{-12}, 3$ seri dari pengenceran terakhir diambil masing-masing $1 \mathrm{ml}$ menggunakan micropipette dan ditumbuhkan pada media MRSA dengan metode tuang (pour plate). Diinkubasi pada suhu $37^{\circ} \mathrm{C}$ selama $48-72$ jam. Selanjutnya koloni bakteri asam laktat dipurifikasi. Koloni tunggal yang telah dipurifikasi diambil dan dimasukan ke dalam tabung reaksi yang berisi $5 \mathrm{ml}$ MRSB. Kemudian diinkubasi pada $37^{\circ} \mathrm{C}$ selama 18 72 jam untuk mendapatkan pertumbuhan kultur murni yang maksimal untuk kemudian ditumbuhkan lagi pada media MRSA [3].

\section{Uji Morfologi Makroskopik}

Uji morfologi makroskipik dilakukan dengan melihat langsung isolat yang tumbuh pada media agar meliputi warna, bentuk, tepi, permukaan serta sudut elevasi yang terbentuk pada isolat.

\section{Uji Morfologi Mikroskopik (Pewarnaan Gram)}

Pewarnaan gram dimulai dengan membersihkan kaca obyek menggunakan alkohol. Teteskan larutan garam fisiologis sebanyak 1-2 tetes di kaca obyek. Bakteri tersebut disebarkan pada larutan garam fisiologis pada kaca obyek secara aseptik. Dilakukan fixsasi panas langsung, kemudian meneteskan kaca benda dengan Kristal violet selama kurang lebih 2 menit. Buang sisa zat warna dan bilas menggunakan aquades. Selanjutnya meneteskan lugol selama 45 detik sampai 1 menit selanjutnya dibilas menggunakan aquades. Langkah ke tiga adalah pelunturan (bleaching) dengan aseton dengan cara disiram dengan posisi kaca obyek miring sampai kelebihan zat warna hilang dibilas. Langkah selanjutnya teteskan zat warna kedua yaitu safranin selama 1-2 menit, kemudian bilas menggunakan aquades. Preparat siap untuk diamati dengan mikroskop.

\section{Uji Ketahanan Terhadap pH Rendah}

1 gram dadih disuspensi dalam $10 \mathrm{ml}$ MRSB yang diatur keasamannya menggunakan $\mathrm{HCl}$ sampai $\mathrm{pH} 3,0$ untuk uji ketahanan $\mathrm{pH}$ rendah dan $\mathrm{pH} 7$ untuk kontrol, kemudian diinkubasi selama 1 jam pada suhu $37^{\circ} \mathrm{C}$. Suspensi kultur dibuat pengenceran 
$10^{-10}, 10^{-11}$ dan $10^{-12}$. Pada setiap pengenceran diambil $1 \mathrm{ml}$ secara aseptik dan ditanam pada media MRSA kemudian diinkubasi pada suhu $37^{\circ} \mathrm{C}$ selama 48 jam dan koloni dihitung menggunakan colony counter [5].

\section{Uji Ketahanan Terhadap Garam Empedu}

1 gram sampel dimasukkan ke dalam $9 \mathrm{ml} \mathrm{NaCl}$ $0,85 \%$. Setelah dilakukan pengenceran berseri, suspensi kultur pada tingkat pengenceran $10^{-7}, 10^{-}$ ${ }^{8}$ dan $10^{-9}$ dilakukan pada MRSA $+0,3 \%$ garam empedu/bile salts dan pada MRSA kontrol dalam cawan petri, dengan metode tuang lalu diinkubasi pada $37^{\circ} \mathrm{C}$ selama $24-48$ jam dan koloni dihitung menggunakan colony counter [5]

\section{Uji Aktivitas Antibakteri}

Isolat bakteri asam laktat berumur 24 jam di tanam pada Nutrient Broth (NB) dan diinkubasi selama 24-48 jam pada suhu $34^{\circ} \mathrm{C}$. Selanjutnya medium yang berisi isolat bakteri di shaker dengan kecepatan $150 \mathrm{rpm}$ selama 24-72 jam. Setelah itu dilakukan pemisahan sel bakteri dan supernatan dengan sentrifugasi dengan kecepatan $5000 \mathrm{rpm}$ selama 30 menit. Supernatan dan pelletnya dipisahkan, selanjutnya supernatan diuji aktivitas antibakterinya terhadap pertumbuhan bakteri pathogen Escherichia Coli [5].

Tabel 1. Kategori kekuatan aktivitas antimikroba [11].

\begin{tabular}{ll}
\hline Diameter & Kekuatan Daya Hambat \\
\hline$\leq 5 \mathrm{~mm}$ & Aktivitas Lemah \\
$6-10 \mathrm{~mm}$ & Aktivitas Sedang \\
$11-20 \mathrm{~mm}$ & Aktivitas Kuat \\
$\geq 21 \mathrm{~mm}$ & Aktivitas Sangat kuat \\
\hline
\end{tabular}

Bakteri patogen uji yang digunakan dalam penelitian ini adalah Escherichia coli. Bakteri patogen berumur 24 jam diambil dengan ose lalu dicampurkan ke dalam garam fisiologis sebanyak 9 $\mathrm{ml}$ kemudian dihomogenkan sampai suspensi bakteri setara dengan Mc Farland 1. Suspensi bakteri patogen dituang ke dalam cawan petri steril sebanyak $1 \mathrm{ml}$ dan dicampurkan dengan $20 \mathrm{ml}$ Muller Hinton Agar (MHA) cair kemudian dihomogenkan dan dibiarkan memadat. Membuat sumuran yang bediameter $6 \mathrm{~mm}$ dengan menggunakan Cork Borer steril. Setiap cawan berisi 3 sumuran. Lubang tersebut diisii dengan supernatan bakteri asam laktat sebanyak $50 \mu \mathrm{L}$. Kultur kemudian diinkubasi pada suhu $34^{\circ} \mathrm{C}$ selama 24 jam. Bakteri asam laktat yang memiliki aktivitas antibakteri akan menghambat pertumbuhan bakteri patogen yang ditandai dengan adanya zona bening di sekitar sumuran. Kategori kekuatan aktivitas antibakteri isolat bakteri asam laktat diukur menggunakan standar kepekaan bakteri seperti pada Tabel 1.

\section{ANALISIS DATA}

Perhitungan koloni/ml dadih susu kambing etawa menggunakan rumus dari Fardiaz (1992) dalam Nuzuludin, dkk (2015) sebagai berikut:

$\frac{\text { Koloni }}{\mathrm{ml}}$
$=$ jumlah koloni percawan $\mathrm{x} \frac{1}{\text { faktor pengenceran }} \times$ volume inokul

Perhitungan jumlah koloni bakteri pada semua cawan menggunakan rumus dari Cappucino (2008) dalam Bahri (2014) sebagai berikut:

$$
\mathrm{K}=\frac{\left(\mathrm{a} \times 10^{\mathrm{e}}\right)+\left(\mathrm{b} \times 10^{\mathrm{f}}\right)}{2}
$$

Keterangan: $\mathrm{K}=$ Banyak koloni $(\mathrm{CFU} / \mathrm{ml})$; $\mathrm{a}$ dan $\mathrm{b}$ $=$ Jumlah koloni bakteri; $\mathrm{e}$ dan $\mathrm{f}=$ Faktor Pengenceran

Setelah didapat nilai jumlah populasi selanjutnya dihitung persentase jumlah populasi dengan rumus sebagai berikut:

$$
\begin{aligned}
& \text { Viabilitas(\%) } \\
& =\frac{\text { Log jumlah sel setelah perlakuan }}{\text { Log jumlah sel sebelum perlakuan }} \times 100
\end{aligned}
$$

(yang dimodifikasi dari Rizqiati dkk., 2005 dalam Kholifath, 2006).

\section{HASIL DAN PEMBAHASAN}

Bakteri kandidat probiotik harus bertahan hidup dalam saluran pencernaan setelah dikonsumsi. Bakteri ini tahan terhadap lisozim, enzim di air liur, asam lambung, garam empedu dan memiliki aktivitas antibakteri [6].

\section{Isolasi dan Identifikasi Bakteri Asam Laktat}

Berdasarkan hasil isolasi yang telah dilakukan diperoleh 2 isolat bakteri asam laktat pada masingmasing bambu berdasarkan pengamatan pada morfologi koloni dan pewarnaan gram. Masingmasing isolat bakteri memiliki ciri morfologi koloni yang berbeda, dapat dilihat pada tabel 2 dan table 3 , Sedangkan morfologi mikroskopik dapat dilihat pada gambar 1-4.

Berdasarkan hasil isolasi yang telah dilakukan diperoleh 2 isolat bakteri asam laktat pada masingmasing bambu berdasarkan pengamatan pada morfologi koloni dan pewarnaan gram. Masingmasing isolat bakteri memiliki ciri morfologi yang berbeda. Koloni B1 dan T1 memiliki ciri-ciri morfologi koloni yakni tepi entire, bentuk circular, 
elevasi raised dan berwarna putih. Sebaliknya pada isolat B2 dan T2 pada fermentasi susu segar kambing etawa dalam bambu Betung dan bambu Tali ditemukan morfologi koloni yang berbeda yakni tepi undulate, bentuk irregular, elevasi raised dan berwarna putih.Hasil pengamatan dengan pewarnaan gram menunjukkan bahwa seluruh isolat bakteri merupakan bergram positif. Sel isolat B1 berbentuk ccocus (bulat) sedangkan sel isolat B2, T1 dan T2 berbentuk basil (batang).

Tabel 2 Morfologi koloni bakteri asam laktat pada susu kambing etawa hasil fermentasi dalam bambu Betung

\begin{tabular}{lllll}
\hline Isolat & Tepi & Bentuk & Elevasi & Warna \\
\hline B1 & Entire & Circular & Raised & Putih \\
B2 & Undulate & Irregular & Raised & Putih \\
\hline
\end{tabular}

Tabel 3 Morfologi koloni bakteri asam laktat pada susu kambing etawa hasil fermentasi dalam bambu Tali.

\begin{tabular}{ccccc}
\hline Isolat & Tepi & Bentuk & Elevasi & Warna \\
\hline T1 & Entire & Circular & Raised & Putih \\
T2 & Undulate & Irregular & Raised & Putih \\
\hline
\end{tabular}

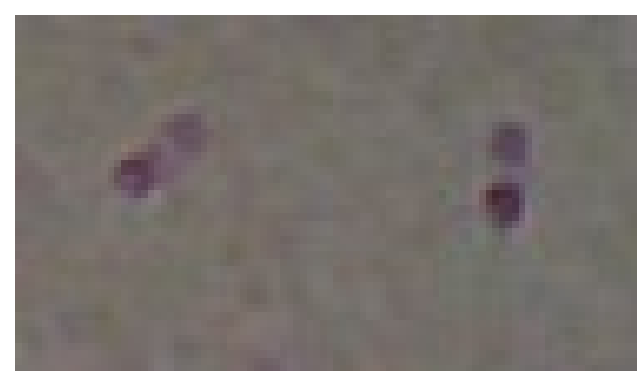

Gambar 1. Morfologi mikroskopis bakteri asam laktat dari hasil fermentasi dalam bambu Betung isolat $\mathrm{B} 1$, merupakan bakteri bergram positif yang berbentuk ccocus

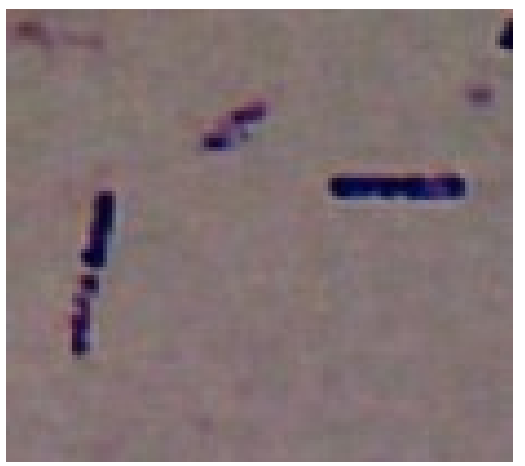

Gambar 2. Morfologi mikroskopis bakteri asam laktat dari hasil fermentasi dalam bambu Betung isolat B2, merupakan bakteri bergram positif yang berbentuk basil.

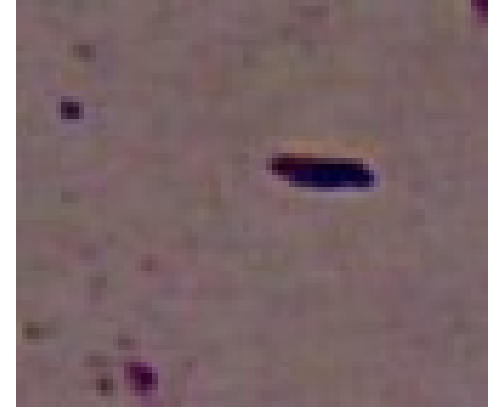

Gambar 3. Morfologi mikroskopis bakteri asam laktat dari hasil fermentasi dalam bambu Tali isolat T1, merupakan bakteri bergram positif yang berbentuk basil.

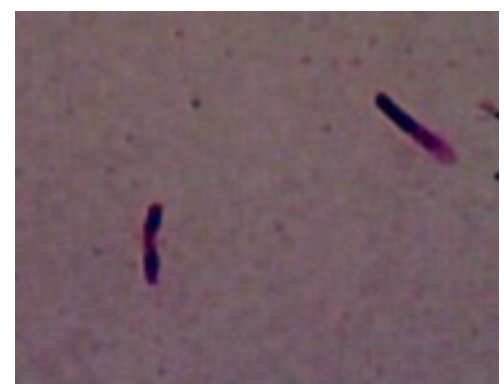

Gambar 4. Morfologi mikroskopis bakteri asam laktat dari hasil fermentasi dalam bambu Tali isolat T2, merupakan bakteri bergram positif yang berbentu basil.

\section{Ketahanan Terhadap pH rendah dan Garam}

Berdasarkan data pada gambar 1, dapat dijelaskan bahwa BAL dari hasil fermentasi susu segar Kambing Etawa dalam bambu Betung dan bambu Tali dapat bertahan pada uji ketahanan terhadap $\mathrm{pH}$ rendah dan uji ketahanan terhadap garam empedu lebih dari 50\%. Isolat kandidat probiotik yang baik adalah isolat yang memiliki ketahanan hidup lebih dari 50\% pada kondisi $\mathrm{pH}$ rendah dan tahan terhadap garam empedu. Secara in vitro bakteri asam laktat yang bertahan dalam $\mathrm{pH} 3,0$ pada dadih susu kambing etawa yang difermentasi dalam bambu Betung sebesar 99.53\%, sedangkan dalam bambu Tali sebesar 95.47\%. Sedangkan bakteri asam laktat yang tahan terhadap garam empedu pada dadih susu kambing etawa yang difermentasi dalam bambu Betung sebesar 94.74\%, sedangkan dalam bambu Tali sebesar 97.96\% [7].

Membran sel pada bakteri yang tidak tahan terhadap $\mathrm{pH}$ rendah akan rusak dan beberapa komponen intraselulerakan keluar dari sel, diantaranya $\mathrm{Mg}^{2+}, \mathrm{Ca}^{-}, \mathrm{K}^{+}$, asam nukleat dan proteinsehingga sel bakteri akan mengalami kematian [8].

Bakteri asam laktat mempunyai tiga sistem pertahanan utama untuk bertahan pada kondisi $\mathrm{pH}$ rendah yaitu sistem glutamate-dekarboksilase 
(GAD), sistem arginin deiminasi (ADI), dan pompa proton $\mathrm{H}^{+}$-ATPase. Bakteri asam laktat mampu bertahan pada kondisi keasaman yang tinggi melalui salah satu sistem pertahanan tersebut. Mekanisme sistem GAD yaitu setelah mengkonsumsi glutamatemelalui suatu transporter spesifik, terjadi dekarboksilasi glutamat di dalamintraseluler, menjadi produk $\gamma$-aminobutyrat (GABA) yang dikeluarkan daridalam sel oleh suatu antiporter, sehingga terjadi peningkatan $\mathrm{pH}$ intraseluler [9].

\section{Empedu}

Hasil penelitian uji probiotik pada hasil fermentasi susu segar kambing etawa dalam bambu Betung dan bambu Tali menunjukkan rata-rata hasil penelitian terhadap uji ketahanan terhadap $\mathrm{pH}$ rendah dan uji ketahanan terhadap garam empedu, dapat dilihat pada gambar 5 .

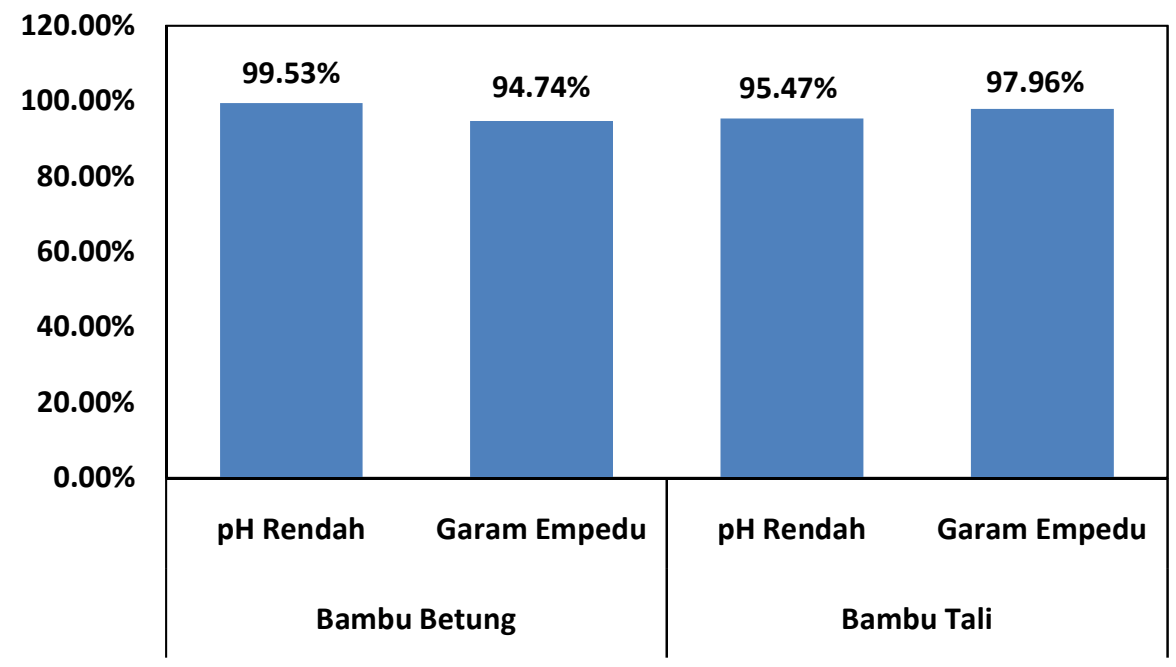

Gambar 5. Persentase viabilitas uji probiotik fermentasi susu kambing etawa dalam bambu Betung dan bambu Tali.

Arginin deiminasi (ADI)merupakan suatu mekanisme homeostatis terhadap kondisi $\mathrm{pH}$ rendah yangdimiliki beberapa BAL dapat mengkatabolisme arginin menjadi ornithin, amonia, dan $\mathrm{CO} 2$. Amonia (NH4) akan meningkatkan $\mathrm{pH}$ internal sitoplasma. Perbedaan toleransi asam pada beberapa spesies BAL berhubungan dengan permeabilitas relatif terhadap proton $\left(\mathrm{H}^{+}\right)$. Permeabilitas sel terhadap $\mathrm{H}^{+}$ salah satunya ditentukan melalui aliran active outflow yang diaktivasi oleh ATPase untuk translokasi $\mathrm{H}^{+}$[9].

Mekanisme pertahanan bakteri asam laktat terhadap garam empedu bakteri asam laktat dapat bertahanterhadap garam empedu karena memiliki kemampuan mendekonjugasigaram empedu.Proses dekonjugasi terjadi karena bakteri memproduksi enzim BileSalt Hydrolase (BSH). Enzim tersebut memiliki manfaat sebagai mekanisme pertahanan melawan keasaman intraseluler yang disebabkan oleh garam empedu terkonjugasi. Garam empedu terkonjugasimengandung gugus karboksil pada asam aminonya. Gugus karboksilmerupakan sumber ion hidrogen. Ikatan kovalen antara oksigen danhidrogen sangat polar sehingga hidrogen cenderung terurai menjadi $\mathrm{H}^{+}$,dengan terakumulasinya $\mathrm{H}^{+}$dari garam empedu terkonjugasimenyebabkan $\mathrm{pH}$ menurun (lebih asam) sehingga mengganggu kestabilangradien proton atau pompa proton dalam membran sel. Enzim BSH akanmengubah garam empedu terkonjugasi menjadi garam empeduterdekonjugasi yang dapat mengurangi penurunan $\mathrm{pH}$. Proses dekonjugasi tersebut adalah menghidrolisis atau memutuskanikatan C-24 N-acyl amida yang terbentuk diantara asam empedu dan asamamino pada garam empedu terkonjugasi [10].

\section{Aktivitas Antibakteri}

Hasil penelitian uji probiotik pada hasil fermentasi susu segar kambing etawa dalam bambu Betung dan bambu Tali menunjukkan rata-rata diameter zona bening, hasil penelitian antibakteri terhadap Escherichia coli, dapat dilihat pada tabel 4.

Berdasarkan data pada tabel 4 dapat dijelaskan bahwa BAL dari hasil fermentasi susu segar Kambing Etawa dalam bambu Betung dan bambu Tali, memiliki rata-rata zona hambat yang berbeda. Pada isolat B1 dan B2 yang merupakan isolat dari fermentasi susu segar Kambing Etawa dalam bambu Betung berkategori aktivitas sedang dengan memiliki rata-rata zona hambar 8-10 $\mathrm{mm}$. 
Sedangkan Pada isolat T1 dan T2 yang merupakan isolat dari fermentasi susu segar Kambing Etawa dalam bambu Tali berkategori tidak beraktivitas karena tidak adanya zona bening yang terbentuk.

Tabel 4 Rata-rata diameter zona bening bakteri asam laktat terhadap Escherichia coli

\begin{tabular}{|c|c|c|c|c|c|}
\hline \multirow[b]{2}{*}{ Isolat } & \multicolumn{3}{|c|}{ Diamater Zona Hambat Ulangan (mm) } & \multirow{2}{*}{$\begin{array}{l}\text { Rata-Rata } \\
(\mathrm{mm})\end{array}$} & \multirow[b]{2}{*}{ Kategori } \\
\hline & 1 & 2 & 3 & & \\
\hline $\mathrm{B} 1$ & 8 & 0 & 8 & 8 & Aktivitas Sedang \\
\hline $\mathrm{B} 2$ & 10 & 10 & 9 & 10 & Aktivitas Sedang \\
\hline $\mathrm{T} 1$ & 0 & 0 & 0 & 0 & Tidak beraktivitas \\
\hline $\mathrm{T} 2$ & 0 & 0 & 0 & 0 & Tidak beraktivitas \\
\hline
\end{tabular}

Mekanisme aktivitas antibakteri bakteri asam laktat adalah asam laktat yang dihasilkan akan berdifusi ke dalam sel bakteri patogen dalam bentuk tak terdisosiasi. Proton $\mathrm{H}^{+}$akan menembus membran sel sehingga akan mempengaruhi integritas membran sitoplasma dan terjadi pengasaman sel. Akibatnya akan terjadi denaturasi protein dan membran sitoplasma akan rusak. Proton $\mathrm{H}^{+}$dalam sitoplasma bakteri patogen akan menganggu gradien proton dan selanjutnya akan mengganggu trasportasi nutrien, sehingga Proton $\mathrm{H}^{+}$harus dikelurakan dari sel. Asam laktat mampu menurunkan $\mathrm{pH}$ dalam sel dan keadaan ini akan mengganggu aktivitas enzim bakteri patogen sehingga metabolisme sel terganggu yang mengakibatkan produksi energi dalam sel terbatas. Energi yang tersedia menjadi berkurang karena digunakan untuk pelepasan ion $\mathrm{H}^{+}$dari sel akibatnya sel akan mati [3].

\section{KESIMPULAN}

Berdasarkan hasil penelitian dan pembahasan, dapat disimpulkan bahwaisolat bakteri asam laktat dari susu Kambing Etawa yang difermentasi dalam bambu Betung berpotensi sebagai probiotik. Berdasarkan pada kesimpulan penelitian ini, disarankan bahwa:

1. Diharapkan adanya penelitian lanjutan untuk mengidentifikasi spesies bakteri asam laktat dari hasil fermentasi susu kambing etawa dalam bambu Betung dan bambu Tali.

2. Diperlukan penelitian lanjutan untuk mengetahui asal bakteri yang berperan dalam fermentasi dadih.

3. Perlu dilakukan uji antibakteri dengan spesies bakteri yang lain untuk melihat potensi antibakteri dari bakteri asam laktat asal dadih susu kambing etawa yang difermentasi dalam bambu Betung dan bambu Tali.

\section{DAFTAR PUSTAKA}

[1] Suwito, W. (2012). Teknologi Penanganan Susu Yang Baik Dengan Mencermati Profil Mikroba Susu Sapi di berbagai daerah. Jurnal Penelitian Pascapanen Pertanian, 9(1), 35-44.
[2] Darkuni, N. 2001.Mikrobiologi. Malang: JICA.

[3] Elida M.2002.Profil Bakteri Asam Lakatat dari Dadih yang Difermentasi dalam Berbagai Jenis Bambu dan Potensinya Sebagai Probiotik.Skripsi. Bogor: Institut Pertanian Bogor.

[4] Azria. 1986.Mikrobiologi dalam Pembuatan Dadih Susu Sapi. Bogor: Institut Pertanian Bogor, Fakultas Teknologi Pertanian.

[5] Usmiati Sri, dkk. 2011. Karakteristik Dadih Susu Sapi uang Menggunakan Starter Bakteri Probiotik. Bogor: Balai Besar Penelitian dan Perkembangan Pascapanen Pertanian. JITV Vol. 16 No. 2. Hal 141-153.

[6] Ingrid, S. 2016. Probiotik, Mikrobiome dan Pangan Fungsional. Yogyakarta: Grup Penerbitan CV Budi Utama.

[7] Nurnaafi, A., \& Setyaningsih, I. (2015). Potensi Probiotik Bakteri Asam Laktat Asal Bekasam Ikan Nila. Jurnal Teknologi dan Industri Pangan, 26(1), 109-114..

[8] Nur, S. 2014. Akteri Asam Laktat Asal BekasamSebagai Kandidat Probiotik. Skripsi. Bogor: Institut Pertanian Bogor.

[9] Cotter, P.D and C. Hill. 2003. Surviving the acid test: responses of gram-positive bacteria10to low pH. Microbiol. Mol. Biol. Rev. 67:429-453

[10] Silvy F.2014. Pengaruh Penambahan Isomalt danLama Penyimpanan Terhadap KetahananLactobacillus acidophilus Fncc 0051 Terimobildalam Gel Alginat pada Asam Lambung DanGaram Empedu Secara In Vitro. Skripsi. Bogor: Institut Pertanian Bogor.

[11] Surjowardojo, P., Susilawati, T. E., \& Sirait, G. R. (2016). Daya Hambat Dekok Kulit Apel Manalagi (Malus sylvestrs Mill.) Terhadap Pertumbuhan Staphylococcus aureus dan Pseudomonas sp. Penyebab Mastitis Pada Sapi Perah. TERNAK TROPIKA Journal of Tropical Animal Production, 16(2), 40-48. 